\title{
PENGARUH JENIS FITOPLANKTON TERHADAP KADAR OKSIGEN DI AIR
}

\author{
Lidia Sarah Panggabean, Puji Prastowo \\ Laboratorium Biologi Unimed, Jurusan Biologi, Program Studi Biologi, Universitas Negeri \\ Medan Jl. William Iskandar Psr V Medan Estate \\ Lidyapanggabean@gmail.com
}

\begin{abstract}
ABSTRAK
Penelitian ini dilakukan untuk mengetahui pengaruh jenis fitoplankton dan intensitas cahaya terhadap peningkatan kadar oksigen terlarut di perairan. Penelitian dilakukan di Laboratorium Biologi Universitas Negeri Medan, Sumatera Utara untuk pengambilan data. Penelitian dilaksanakan pada bulan Mei 2017. Variabel penelitian yang digunakan adalah perlakuan dengan jenis fitoplankton dan intensitas cahaya. Jenis fitoplankton yang digunakan adalah fitoplankton Arthospira platensis, Chorella vulgaris, dan Diatom sp. Penelitian menggunakan Rancangan Acak Lengkap (RAL) dengan 4 kali pengulangan. Pengamatan terhadap kadar oksigen terlarut dilakukan setelah 7 hari menggunakan DO meter. Hasil penelitian menunjukkan bahwa terdapat perbedaan signifikan jenis fitoplankton terhadap kadar oksigen di air setelah 7 hari. Ada pengaruh jenis fitoplankton terhadap kadar oksigen terlarut di air.
\end{abstract}

Kata kunci : Oksigen terlarut, Jenis fitoplankton, Intensitas cahaya.

\section{INFLUENCE OF PHYTOPLANKTON TYPES OF OXYGEN CONTENT IN WATERS.}

\author{
Lidia Sarah Panggabean, Puji Prastowo
}

\begin{abstract}
This study was aim to know the influence of phytoplankton on the increase of dissolved oxygen in the waters. The research was conducted in Biology Laboratory State University of Medan, North Sumatera for data retrieval. The research was conducted in May 2017. The research variables used the treatment with the phytoplankton type. Types of phytoplankton used were phytoplankton Arthospira platensis, Chorella vulgaris, and Diatom sp. The study used Complete Block Design with 4 repetitions. Observation of dissolved oxygen level was done after 7 days using DO meter. The results showed that there was not influence of phytoplankton types about oxygen content in water after 7 days. There was an influence of the phytoplankton types on the dissolved oxygen content in water.
\end{abstract}

Keywords: Dissolved Oxygen, Type of phytoplankton, Light intensity.

\section{Pendahuluan}

Permasalahan yang dialami ekosistem perairan saat ini adalah penurunan kualitas air akibat pembuangan limbah ke perairan yang menyebabkan pencemaran. Terjadinya penurunan kualitas air akibat pencemaran maupun secara alami tanpa ulah makhluk hidup dengan sengaja dapat mengganggu keseimbangan ekositem, dikarenakan menurunnya fisika-kimia air yang merupakan sumber kehidupan bagi makhluk hidup air dan mengakibatkan ekosistem yang di dalam maupun di luar kehidupan air terganggu. Menurut

Pencemaran air mengakibatkan penurunan kualitas air seperti penurunan kandungan oksigen terlarut, dan secara alami, kandungan oksigen terlarut dalam perairan juga dapat menurun, pada Michael (1994) oksigen hilang dari air secara alami oleh adanya pernafasan biota, penguraian bahan organik, aliran masuk air bawah tanah yang miskin oksigen dan kenaikan suhu.

Keseimbangan oksigen di perairan perlu dijaga untuk mempertahankan ekosistem. Beberapa mikroalga memiliki kemampuan dalam meningkatkan kadar oksigen terlarut dan menurunkan kadar ammonium dengan menggunakan hasil oksidasi nitrogen dalam bentuk ammonium sebagai materi organik untuk fotosintesis. Mikroalga tersebut dapat berupa 
fitoplankton dan tumbuhan aquatik lainnya. Patty (2014) juga mengatakan sumber utama oksigen di perairan selain dari proses difusi oksigen dari udara adalah dari hasil fotosintesis fitoplankton, sehingga tingginya kandungan oksigen di perairan akan mencirikan tingginya kelimpahan organisme fitoplankton pada perairan tesebut.

Kelompok fitoplankton yang mendominasi perairan umumnya terdiri dari diatom dan ganggang hijau serta dari kelompok ganggang biru. Arthospira platensis adalah ganggang biru-hijau, yaitu makhluk hidup autotrof berwarna kehijauan, kebiruan, dengan sel berkolom membentuk filamen terpilin menyerupai spiral (helix) sehingga disebut juga alga biru hijau berfilamen (cyano bacterium) (Hariyati, 2008). Chorella vulgaris termasuk ke dalam family Chloropyta, yang mempunyai zat warna hijau Nama alga hijau diberikan karena kandungan zat hijau (chlorophyll) yang dimilikinya sangat tinggi, bahkan melebihi jumlah yang dimiliki oleh beberapa tumbuhan tingkat tinggi. Diatom merupakan fitoplankton yang bersifat uniseluler yang termasuk dalam kelas Bacillariophyceae (Wilianto 2012). Menurut Roito (2014), diatom adalah organisme yang hidupnya melayang atau mengambang di permukaan air sehingga kemampuan geraknya sangat terbatas dan menyebabkan organisme tersebut terbawa oleh arus.

Cahaya merupakan kebutuhan utama untuk fitoplankton dalam melakukan proses fotosintesis. Menurut Utami (2012), cahaya lampu yang digunakan dalam laboratorium untuk menggantikan cahaya matahari adalah sebesar 20 watt dengan spesifikasi lampu yang mendekati spesifikasi cahaya matahari.

Oksigen terlarut (Dissolved Oxygen $=$ DO) dibutuhkan oleh semua jasad hidup untuk pernapasan, proses metabolisme atau pertukaran zat. Kandungan oksigen terlarut (DO) minimum adalah $2 \mathrm{ppm}$ dalam keadaan nornal dan tidak tercemar oleh senyawa beracun (toksik) (Salmin 2005).

\section{Bahan dan metode}

Penelitian ini dilaksanakan di Laboratorium Biologi Universitas Negeri Medan, Sumatera Utara untuk pengambilan data. Penelitian dilaksanakan pada bulan Mei 2017. Metode dalam penelitian adalah eksperimen menggunakan Rancangan Acak Lengkap (RAL) dengan variabel bebas yaitu jenis fitoplankton, sedangkan variable terikat adalah kadar oksigen terlarut. . Jenis fitoplankton yang digunakan adalah : Arthospira platensis, Chorella vulgaris, dan Diatom sp. dan kontrol tanpa pemberian fitoplankton pada intensitas cahaya 107 lux.

Air sumur yang telah disediakan dimasukkan kedalam setiap wadah ember masing-masing 15 L. Pengukuran kadar oksigen terlarut dilakuan sebelum diberikan perlakuan dengan berbagai jenis fitoplankton untuk memastikan bahwa setiap wadah memiliki kadar oksigen yang sama sebelum diberi perlakuan. Sampel kultur murni fitoplankton (Arthospira platensis, Chorella vulgaris, Diatom sp.) sebanyak 1 disaring untuk diambil berat segarnya menggunakan net plankton. Kemudian ditimbang menggunakan timbangan analitik dengan ketelitian $0,1 \mathrm{~g}$, dan digunakan untuk setiap percobaan adalah $5 \mathrm{~g}$ dalam 15 liter air. Selanjutnya fitoplankton dimasukkan ke dalam wadah ember mulai dari wadah ember A berisi Arthospira platensis, wadah ember B berisi Chorella vulgaris, wadah ember $\mathrm{C}$ berisi Diatom sp., dan wadah ember D sebagai kontrol. Perlakuan yang sama dilakukan untuk ulangan dari masing-masing perlakuan. Wadah ember pada masingmasing intensitas cahaya disusun dengan menggunakan Rancangan Acak Lengkap (RAL) yang diambil secara diundi. Pengukuran oksigen terlarut pada setiap wadah ember setelah 7 hari. Data hasil pengukuran kadar oksigen dimasukkan dalam format tabel. Data dianalisis menggunakan Analisa Varian (ANOVA) untuk mengetahui ada tidaknya beda nyata antar perlakuan dengan menggunakan program SPSS versi 22.0.0.0. Analisis dilanjutkan dengan uji Duncan dengan taraf signifikasi $95 \%$ bila terdapat beda nyata. 


\section{Hasil Dan Pembahasan}

\section{Hasil}

Dari penelitian yang telah dilakukan, diperoleh hasil sebagai berikut :

Tabel 1. Kadar oksigen terlarut (ml/L) pada hari ke-7 dengan perlakuan jenis fitoplankton dan intensitas cahaya.

\begin{tabular}{|c|c|c|c|c|c|c|}
\hline \multirow{2}{*}{$\begin{array}{c}\text { Jenis } \\
\text { Fitoplankton }\end{array}$} & \multicolumn{4}{|c|}{ Ulangan ke- } & \multirow[t]{2}{*}{$\Sigma$} & \multirow{2}{*}{$\bar{\chi}$} \\
\hline & 1 & 2 & 3 & 4 & & \\
\hline $\begin{array}{l}\text { Arthospira } \\
\text { platensis }\end{array}$ & 6,5 & 6,4 & 6,7 & 6,5 & 26,1 & 6,53 \\
\hline $\begin{array}{l}\text { Chorella } \\
\text { vulgaris }\end{array}$ & 6,4 & 6,3 & 6,4 & 6,4 & 25,5 & 6,38 \\
\hline Diatom sp. & 6,4 & 6,4 & 6,5 & 6,4 & 25,7 & 6,43 \\
\hline Kontrol & 6,1 & 6,1 & 6,1 & 6,2 & 24,5 & 6,13 \\
\hline
\end{tabular}

Dari hasil pengamatan pengukuran kadar oksigen terlarut yang dilakukan dengan menggunakan DO meter, terdapat peningkatan kadar oksigen terlarut setelah diberi perlakuan. Kadar oksigen terlarut sebelum diberi perlakuan pada masing-masing wadah adalah 6,1 $\mathrm{ml} / \mathrm{L}$, kemudian setelah dilakukan pengamatan kadar oksigen terlarut setelah perlakuan pada hari ke-7 dapat dilihat bahwa jenis fitoplankton yang paling tinggi dalam menghasilkan oksigen terlarut adalah Arthospira platensis yaitu 6,53 ml/L pada intensitas cahaya 107 lux, dan yang paling rendah kadar oksigen terlarut pada kontrol yaitu 6,05 $\mathrm{ml} / \mathrm{L}$ pada intensitas cahaya 870 lux.

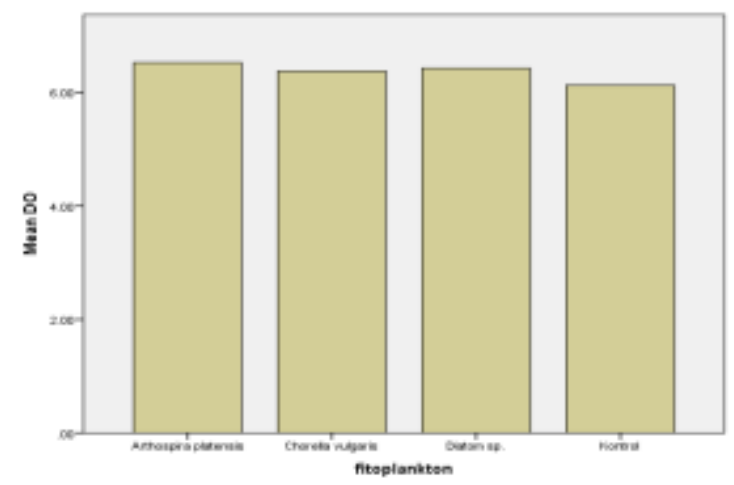

Gambar 1. Grafik data pengamatan kadar oksigen terlarut setelah 7 hari berdasarkan jenis fitoplankton dan intensity as cahaya.
Dari grafik diperoleh bahwa kadar oksigen tertinggi diperoleh oleh Arthospira platensis, dan terendah pada kontrol. Terjadi peningkatan kadar oksigen oleh adanya fitoplankton yang sebelum diberi perlakuan adalah $6,1 \mathrm{ml} / \mathrm{L}$.

Untuk analisis data menggunakan uji statistika ANOVA yang dilanjutkan dengan uji Duncan. Hasil uji statistika menggunakan ANOVA dua jalur untuk kadar oksigen terlarut yang dihasilkan oleh macam fitoplankton dan intensitas cahaya adalah sebagai berikut :

Tabel 2. Hasil uji statistika menggunakan anova dua jalur untuk variasi antar grup terhadap kadar oksigen terlarut.

\begin{tabular}{|c|c|c|c|c|c|c|}
\hline \multirow{2}{*}{$\begin{array}{l}\text { Sumber } \\
\text { Variasi }\end{array}$} & \multirow[t]{2}{*}{ df } & \multirow[t]{2}{*}{ SS } & \multirow[t]{2}{*}{ MS } & \multirow[t]{2}{*}{$\mathbf{F}_{\text {hit }}$} & \multicolumn{2}{|c|}{$F_{\text {tabel }}$} \\
\hline & & & & & 0,05 & 0,01 \\
\hline Perlakuan & 3 & 0,3175 & 0,105 & $\begin{array}{c}12,6 \\
5\end{array}$ & 3,49 & 5,95 \\
\hline Galat & 12 & 0,1 & 0,0083 & - & - & - \\
\hline Total & 15 & 0,4175 & - & - & - & - \\
\hline
\end{tabular}

Dari hasil uji statistika diatas diperoleh bahwa berdasarkan jenis fitoplankton $F_{\text {hitung }}(12,65)<F_{\text {tabel }}(2,07)$, artinya jenis fitoplankton sangat berpengaruh nyata terhadap kadar oksigen terlarut di air, sehingga dapat disimpulkan bahwa Ha diterima, yaitu terdapat pengaruh jenis fitoplankton terhadap kadar oksigen terlarut di air pada $\alpha=0,05$.

Hasil Penelitian menunjukkan bahwa terdapat perbedaan signifikan ratarata kadar oksigen yang dihasilkan oleh setiap jenis fitoplankton. Kadar oksigen terlarut yang disajikan pada gambar 4.1, terlihat bahwa rata rata kadar oksigen yang dihasilkan oleh setiap jenis fitoplankton berbeda dan pada hasil statistic berbeda nyata signifikan pada saat dilakukan uji statistik pada $\alpha=0,05$.

\section{Pembahasan}

Setiap jenis mikroalga atau fitoplankton memiliki kemampuan fotosintesis yang berbeda-beda. Arthospira platensis menghasilkan oksigen lebih tinggi karena mampu melakukam proses fotosintesis secara optimal. Dan memiliki 
daya tahan terhadap lingkungan yang lebih baik, dilihat dari nilai oksigen yang dihasilkan selama 7 hari lebih konstan antar kelompok dibangding jenis fitoplankton lain. Pada penelitian Abdurrachman, 2013, bahwa Arthospira platensis merupakan mikroalga yang paling optimal dalam penyerapan $\mathrm{CO}_{2}$ sebab memiliki daya adaptasi atau ketahanannya dalam menghadapi stress yang lebih baik sehingga menghasilkan oksigen yang lebih besar. Fitoplankton mampu menghasilkan oksigen terlarut pada saat proses fotosintesis, dimana energi matahari yang diserap oleh klorofil digunakan untuk menguraikan molekul air , mereduksi NADP menjadi NADPH dan membentuk gas oksigen. Fitoplankton mampu mengubah hara anorganik menjadi bahan organik dan penghasil oksigen yang sangat mutlak diperlukan bagi kehidupan mahluk yang lebih tinggi. Dalam ekosistem air, hasil dari fotosintesis yang dilakukan oleh fitoplankton bersama dengan tumbuhan air lainnya yaitu bahan organik dan oksigen disebut sebagai produktifitas primer. Menurut Yulita (2014), beberapa mikroalga atau disebut dengan fitoplankton memiliki kemampuan menghasilkan oksigen terlarut diperairan. Mikroalga aktif dalam melakukan fotosintesis dan mengkonversi $\mathrm{CO}_{2}$ menjadi oksigen sehingga produktivitas oksigen menjadi lebih tinggi.

Dinamika oksigen terlarut dalam ekosistem perairan ditentukan oleh keseimbangan antara produksi dan konsumsi oksigen. Menurut Puspitaningrum (2012), produksi oksigen berlangsung melalui proses fotosintesis oleh komunitas autotrof, sedangkan konsumsi oksigen dilakukan oleh semua organisme melalui proses respirasi dan perombakan bahan organik. Tumbuhan akuatik dan fitoplankton merupakan faktor yang penting dalam menentukan keseimbangan oksigen dalam ekosistem perairan. Tumbuhan aquatik dan fitoplankton efektif meningkatkan kadar oksigen dalam air melalui proses fotosintesis. Karbondioksida dalam proses fotosintesis diserap dan oksigen dilepas ke dalam air.

\section{Kesimpulan}

Berdasarkan hasil penelitian diperoleh bahwa ada pengaruh nyata jenis fitoplankton tehadap kadar oksigen terlarut di air.

\section{Ucapan Terimakasih}

Terimakasih kepada Ibu Dra. Meida Nugrahalia, M.Sc. selaku kepala laboratorium, dan Bapak Agus selaku laboran Biologi Universitas Negeri Medan yang telah membantu selama proses penelitian.

\section{Daftar Pustaka}

Abdurrachman O., Meitiandari M. dan Luqman B. 2013. Pengikatan Karbondioksida dengan Mikroalga (Chorella vulgaris, Clamydomonas sp., Arthospira platensis sp.) dalam Upaya untuk Meningkatkan Kemurnian Biologis. Jurnal Teknologi Kimia dan Industri. 2 (4) : 212-216

Ayu D. 2014. Pengaruh Tiga Jenis Fitoplankton yang Berbeda sebagai Pakan Alami Tingkat Kematangan Gonad Teripang Lokal (Phyllophorus $s p)$. Surabaya : UNAIR.

Hariyati R. 2008. Pertumbuhan dan Biomassa Arthospira platensis sp. dalam Skala Laboratoris. Bioma. 10 (1) : 19-22

Kasim S., Syahrul M. dan Hanapi U. 2013. Pemanfaatan Medium Ars-Chat pada Produksi Biomassa Fitoplankton Laut yang Potensial sebagai Bahan Baku Bioful Jenis Bioetanol. Seminar Nasional FMIPA UNDIKSHA III.

Michael P. 1994. Metode Ekologi Penyelidikan Ladang dan Laboratorium. Jakarta: Universitas Indonesia Press.

Patty S.I. 2014. Karakteristik Fosfat, Nitrat, dan Oksigen Terlarut di Perairan Pulau Gangga dan Pulau Siladen Sulawesi Utara. Jurnal Ilmiah Platax. $2(2): 1-7$

Utami N.P., Yuniarti M.S. dan Kiki H. 2012. Pertumbbuhan Chorella sp. yang Dikultur Pada Perioditas Cahaya yang Berbeda. Jurnal Perikanana dan Kelautan. 3 (3) : 237-244 
Rasyid A. 2009. Distribusi Klorofil-a pada Musim Perairan Barat-Timur di Perairan Spermonde Propinsi Sulawesi Selatan. Jurnal Sains dan Teknologi. 9 (2) : 125-132

Roito M., Yusni I.S. dan Mubarak. 2014. Analisis Struktur Komunitas Diatom Plantonik di Perairan Pulau Topang Kabupaten Kepulauan Meranti Propinsi Riau. Jurnal Perikanan dan Kelautan. 19 (2) : 22-32

Salmin. 2006. Oksigen Terlarut (DO) dan Kebutuhan Oksigen Biologi (BOD) sebagai Salah Satu Indikator untuk Menentukan Kualitas Perairan. Jurnal Oseana. 30 (3) : 21-26

Wilianto W. 2012. Pemeriksaan Diatom pada Korban Diduga Tenggelam. Jurnal Kedokteran Forensik Indonesia. 14 (3) : 39-46 